\title{
Helicobacter marmotae and novel Helicobacter and Campylobacter species isolated from the livers and intestines of prairie dogs
}

Correspondence

James G. Fox

jgfox@mit.edu

Received 11 March 2011

Accepted 30 April 2011

\author{
Maike Beisele, ${ }^{1}$ Zeli Shen, ${ }^{1}$ Nicola Parry, ${ }^{1}$ Melissa Mobley, ${ }^{1}$ \\ Nancy S. Taylor, ${ }^{1}$ Ellen Buckley, ${ }^{1}$ Mohammad Z. Abedin, ${ }^{4}$ \\ Floyd E. Dewhirst ${ }^{2,3}$ and James G. Fox ${ }^{1}$ \\ ${ }^{1}$ Division of Comparative Medicine, Massachusetts Institute of Technology, Cambridge, MA 02139, \\ USA \\ ${ }^{2}$ Department of Molecular Genetics, Forsyth Institute, Cambridge, MA 02142, USA \\ ${ }^{3}$ Department of Oral Medicine, Infection and Immunity, Harvard School of Dental Medicine, Boston, \\ MA 02115, USA \\ ${ }^{4}$ Drexel University College of Medicine, Philadelphia, PA 19102, USA
}

\begin{abstract}
Prairie dogs (Cynomys ludovicianus) are used to study the aetiology and prevention of gallstones because of the similarities of prairie dog and human bile gallstone composition. Epidemiological and experimental studies have suggested a connection between infection with Helicobacter species and cholesterol cholelithiasis, cholecystis and gallbladder cancer. Ten of the 34 prairie dogs in this study had positive Helicobacter species identified by PCR using Helicobacter genusspecific primers. Ten of 34 prairie dogs had positive Campylobacter species identified in the intestine by PCR with Campylobacter genus-specific primers. Six Helicobacter sp. isolates and three Campylobacter sp. isolates were identified taxonomically by $16 \mathrm{~S}$ rRNA gene analysis. The prairie dog helicobacters fell into three clusters adjacent to Helicobacter marmotae. On the basis of $16 \mathrm{~S}$ rRNA gene sequence analysis, three strains in two adjacent clusters were included in the species $H$. marmotae. Three strains were only $97.1 \%$ similar to the sequence of $H$. marmotae and can be considered a novel species with the provisional designation Helicobacter sp. Prairie Dog 3. The prairie dog campylobacters formed a single novel cluster and represent a novel Campylobacter sp. with the provisional designation Campylobacter sp. Prairie Dog. They branched with Campylobacter cuniculorum at $96.3 \%$ similarity and had the greatest sequence similarity to Campylobacter helveticus at $97.1 \%$ similarity. Whether $H$. marmotae or the novel Helicobacter sp. and Campylobacter sp. identified in prairie dogs play a role in cholesterol gallstones or hepatobiliary disease requires further studies.
\end{abstract}

\section{INTRODUCTION}

Bacteria belonging to the genus Helicobacter are now recognized as a common inhabitant of the hepatobiliary and gastrointestinal tract of mammals. These Gram-negative enterohepatic bacteria have become the subject of intense research because of their association with gastrointestinal diseases (Fox, 2002; Kobayashi et al., 2005; Pellicano et al., 2008). Helicobacter species have been isolated and identified from the gastrointestinal tract of humans, dogs, cats, ferrets,

Abbreviations: IVS, intervening sequence; MIT, Massachusetts Institute of Technology.

The GenBank/EMBL/DDBJ accession numbers for the isolates sequence in this study are GU902715-GU902720 (Helicobacter) and HM211850-HM211852 (Campylobacter). pigs, cattle, monkeys, dolphins, seals and cheetahs, and are associated with variable degrees of pathology in their respective hosts (Whary \& Fox, 2004). In humans, Helicobacter pylori causes peptic ulcers and, because of its association with gastric adenocarcinoma, is classified as a class I carcinogen by the World Health Organization (Fox \& Wang, 2007). In recent years, enterohepatic Helicobacter species have also been isolated from wild and laboratory rodents (Comunian et al., 2006; Fox et al., 2002, 2010; Franklin et al., 1996; Goto et al., 2004; Won et al., 2002; Zenner, 1999).

Epidemiological and experimental studies have suggested a connection between infection with Helicobacter species and cholesterol cholelithiasis, cholecystitis, and gallbladder cancer (Fox et al., 1998; Maurer et al., 2005). Prairie dogs 
are used to study gallstone aetiopathogenesis and prevention (Davis et al., 2003; Li et al., 1994; Narins et al., 2005; Strichartz et al., 1989) and electrogenic bicarbonate secretion in the gallbladder (Moser et al., 2007).

We hypothesized that prairie dogs, like other wild rodents, harbour Helicobacter species, and that these microaerophilic bacteria might be associated with overt or subclinical disease and might affect research studies. The goal of this study was to determine whether Helicobacter species could be isolated from the gastrointestinal tract and/or liver of prairie dogs, which are used as models to study gallbladder physiology because of the similarities of prairie dog and human bile gallstone composition. It is also recognized that Helicobacter species co-colonize with a variety of Campylobacter species in the intestines of humans, dogs and cats (Fox et al., 1995; Lastovica \& le Roux, 2000; Rossi et al., 2008; Shen et al., 2001). We therefore asked whether Campylobacter species could also be identified in the gastrointestinal tract of prairie dogs.

\section{METHODS}

Animals. Adult, black-tailed male and female prairie dogs (Cynomys ludovicianus), trapped in the wild, were purchased from Flyers Speciality Pets (Lubbock, TX, USA). The prairie dogs were caged individually in a $23{ }^{\circ} \mathrm{C}$ thermoregulated room at the Drexel University College of Medicine, PA, USA. These animals were used for studies of cholesterol gallstone pathophysiology. From 2004 to 2008, selected samples of liver, caecum and faecal specimens from 34 adult prairie dogs, of both sexes, were collected during necropsy. In 13 animals, liver and caeca from the same prairie dog were available for culture. In another eight prairie dogs, faeces only were cultured; from two prairie dogs, gallbladder and liver cultures were grown, and from 11 prairie dogs only livers were cultured. The specimens were shipped to the Massachusetts Institute of Technology (MIT; MA, USA) on dry ice and stored immediately at $-70{ }^{\circ} \mathrm{C}$ until evaluated by culture and PCR analysis. All experiments were approved by the Drexel Institutional Animal Care and Use Committee.

Microaerobic culture and biochemical characterization. Liver and caecal tissues were rinsed with sterile physiological saline and placed in a vial with $1.5 \mathrm{ml} 20 \%$ glycerol in Brucella broth (Remel). Vials were maintained at $-70{ }^{\circ} \mathrm{C}$ prior to culture. Samples were plated on tryptic soy agar (BBL), CVA medium (containing cefoperazone, vancomycin and amphotericin B; Remel) and blood agar base (Oxoid) media containing amphotericin, vancomycin, polymyxin, bacitracin and nalidixic acid (Sigma Chemical Company). A small amount of tissue or faeces was homogenized in $1 \mathrm{ml}$ Brucella broth containing $5 \%$ fetal calf serum (ATLAS Biolabs) in a disposable plastic tissue grinder. Approximately $100 \mu \mathrm{l}$ sample was applied and streaked directly onto the three selective media. Half of the remaining sample was filtered through a $0.45 \mu \mathrm{m}$ pore-size filter onto a blood agar plate. The plates were incubated at $37{ }^{\circ} \mathrm{C}$ under microaerobic conditions as described previously (Fox et al., 2006). A detailed biochemical characterization analysis was performed on selected isolates of Campylobacter species and Helicobacter species as described previously (Shen et al., 2001).

DNA extraction for PCR analysis. A High Pure PCR Template Preparation kit (Roche Molecular Biochemicals) was used for extraction of DNA from the bacterial isolates and the tissue samples according to the manufacturer's direction. A QAIamp DNA Stool Mini kit (Qiagen) was used to extract DNA from faecal samples.

PCR amplification of bacterial DNA. Helicobacter genus-specific primers C97 and C05 and Campylobacter genus-specific primers C98 and C99 were used to amplify a $1.2 \mathrm{~kb}$ and a $420 \mathrm{bp}$ PCR fragment, respectively, as described previously (Fox et al., 1998; Shen et al., 2001).

Nested PCR. The $1.2 \mathrm{~kb}$ PCR product from Helicobacter genusspecific primers C97 and C05 amplified from the DNA of 21 liver specimens was subjected to nested PCR using Helicobacter genusspecific primer C98F (5'-TGGTGTAGGGGTAAAATCC-3'), which is the reverse complement of primer C98 (Fox et al., 1998), and H3A20 (5'-GCCGTGCAGCACCTGTTTC-3') (Bohr et al., 2002) to generate 386 bp fragments. Briefly, $5 \mu$ PCR product using primers C97 and C05 was used for another PCR amplification using primers C98F and H3A20 under the same reaction and cycling conditions (Fox et al., 1998). Fifteen microlitres of the sample was then electrophoresed through a $2 \%$ agarose gel followed by ethidium bromide staining, and visualized by UV illumination.

RFLP analysis. The PCR-amplified $1.2 \mathrm{~kb}$ fragment of the $16 \mathrm{~S}$ rRNA gene $(20 \mu \mathrm{l})$ was digested with $10 \mathrm{U} A l u \mathrm{I}$ and HhaI (New England BioLabs) in appropriate buffer, as recommended by the manufacturer, at $37^{\circ} \mathrm{C}$ for $3 \mathrm{~h}$ (Shen et al., 2000). Restriction patterns were compared after the digested PCR products had been separated on a $6 \%$ Visigel separation matrix (Stratagene).

Amplification of the 16S rRNA cistron by PCR and purification of the PCR product from cultured bacteria. The rRNA cistron from isolates of Helicobacter species (accession numbers MIT 048588, MIT 07-6167, MIT 07-5168, MIT 07-5155 and MIT 07-5158) and Campylobacter species (MIT 07-5155, MIT 07-5158 and MIT 075167) were amplified using the universal bacterial primers F24 and F25 for the 16S rRNA gene (Fox et al., 1998). Hot-start PCR was performed in thin-walled tubes with a Perkin-Elmer 9700 thermocycler and $1 \mu \mathrm{l}$ DNA template was added to a reaction mixture $(50 \mu \mathrm{l}$ volume) containing $20 \mathrm{pmol}$ each primer, $40 \mathrm{nmol}$ dNTPs and $1 \mathrm{U}$ Taq 2000 polymerase (Stratagene) in buffer containing Taqstart antibody (Sigma). Amplification was achieved using a previously described method (Marini et al., 2010).

165 rRNA gene sequencing and data analysis. Three purified DNA samples from 2004 and three from 2007 were sequenced with an ABI PRISM cycle-sequencing kit (BigDye Terminator Cycle Sequencing kit with AmpliTaq DNA polymerase FS; Perkin-Elmer). The primers used have been described previously by Fox et al. (1998). Quarterdye chemistry was used with $80 \mu \mathrm{M}$ primers and $1.5 \mu \mathrm{l}$ PCR product in a final volume of $20 \mu \mathrm{l}$. Cycle sequencing was performed with an ABI GeneAmp PCR System 9700 with 25 cycles of denaturation at $96{ }^{\circ} \mathrm{C}$ for $10 \mathrm{~s}$ and annealing and extension at $60{ }^{\circ} \mathrm{C}$ for $4 \mathrm{~min}$. Sequencing reactions were run on an ABI $3100 \mathrm{DNA}$ instrument. Sequence data were entered into RNA, a program set for data entry, editing, sequence alignment, secondary structure comparison, similarity matrix generation and dendrogram construction for 16S rRNA (Dewhirst et al., 1999). Our database contains over 1000 sequences obtained in our laboratory and over 500 retrieved from GenBank for $16 \mathrm{~S}$ rRNA. Dendrograms were constructed by the neighbour-joining method (Saitou \& Nei, 1987).

Histopathology. Selected specimens of liver from five prairie dogs were shipped to MIT in vials containing neutral-buffered $10 \%$ formalin. The tissues were processed by standard histological methods and embedded in paraffin, and $5 \mu \mathrm{m}$ sections were stained with haematoxylin and eosin and evaluated by a comparative pathologist. 


\section{RESULTS}

\section{Microaerobic culture and biochemical characterization of Helicobacter marmotae and novel Helicobacter and Campylobacter species}

After incubation under microaerobic conditions, bacterial growth was visible as a thin, spreading film. Helicobacter species were confirmed using catalase, oxidase and urease activity, as well as cell morphology, lack of growth aerobically and PCR using Helicobacter species-specific primers. Helicobacter was isolated from the faeces or caecal tissue of five of the 34 prairie dogs and from the liver of one animal. In the 13 prairie dogs in which tissue samples from both the liver and caeca were available, pure cultures of Helicobacter species were isolated from the caeca of two animals (MIT 07-5165 and 07-5168) and the liver of a third (MIT 07-5167). In the eight prairie dogs from which faeces were cultured, Helicobacter species were isolated from three animals (MIT 04-8584, 04-8589 and 04-8588). The bacteria were Gram-negative and grew under microaerobic conditions at 37 and $42{ }^{\circ} \mathrm{C}$ and $25{ }^{\circ} \mathrm{C}$. All isolates were oxidase positive and urease negative. The bacteria did not hydrolyse indoxyl acetate or show alkaline phosphatase activity, and did not reduce nitrate to nitrite; they did not have $\gamma$-glutamyl transpeptidase activity. They did not grow in $1 \%$ glycine and were resistant to cephalothin, except for 04-8584, but were sensitive or showed intermediate resistance to nalidixic acid (Table 1).

Despite culturing all specimens from the 34 prairie dogs for Campylobacter species, a pure culture of a novel Campylobacter sp. was isolated from only three animals: from the caecum of two animals and from the liver of a third. The bacteria were Gram-negative and grew under microaerobic conditions at $42{ }^{\circ} \mathrm{C}$ and $37{ }^{\circ} \mathrm{C}$. All isolates were oxidase and catalase positive but urease negative. The bacteria hydrolysed indoxyl acetate but did not show alkaline phosphatase activity, and did not reduce nitrate to nitrite; they did not have $\gamma$-glutamyl transpeptidase activity. They did not grow in $1 \%$ glycine and were resistant to cephalothin but sensitive to nalidixic acid (Table 2).

\section{PCR identification of Helicobacter species}

Ten of the 34 prairie dogs were positive for Helicobacter species by PCR with Helicobacter genus-specific primers (C97 and CO5). Six of these ten were amplified from pure culture. In addition, two of the five prairie dog liver samples also analysed by histopathology that were negative using conventional PCR were positive for Helicobacter species using nested PCR. Overall, Helicobacter species were detected in nine out of 20 males and three out of 14 females.

\section{PCR identification of Campylobacter species}

Campylobacter species were identified by PCR using Camyplobacter genus-specific primers (C98 and C99) in three out of 20 males and seven out of 14 females.

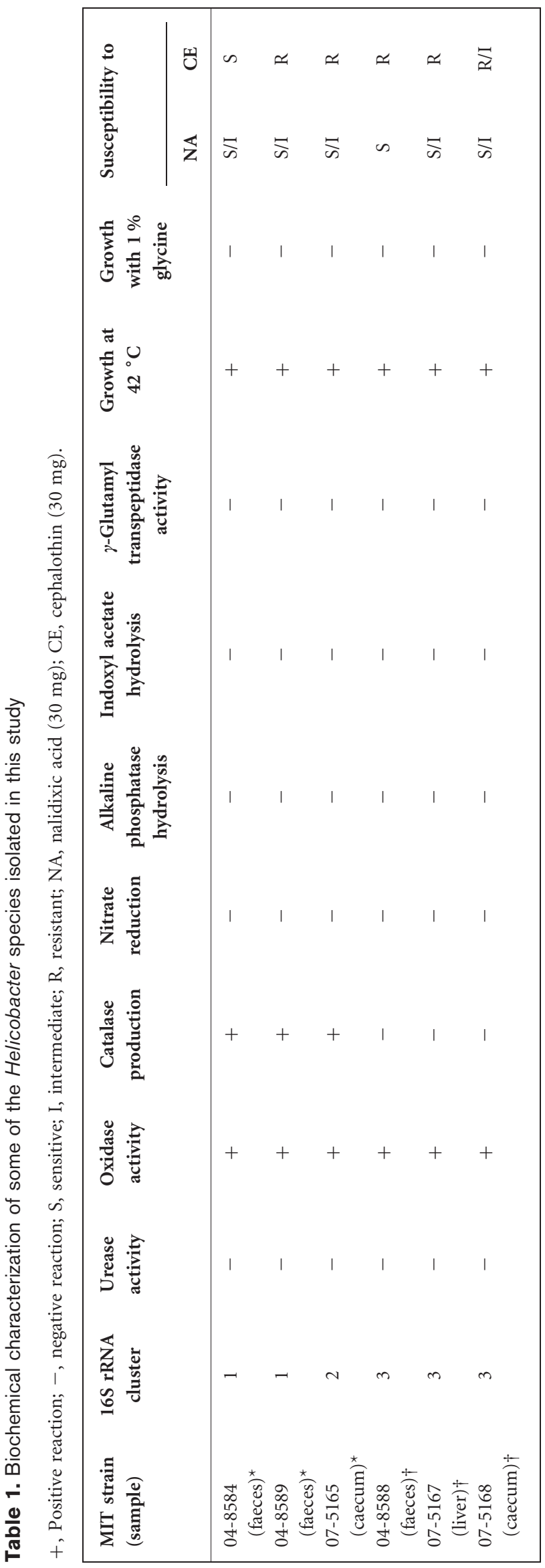

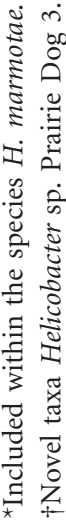




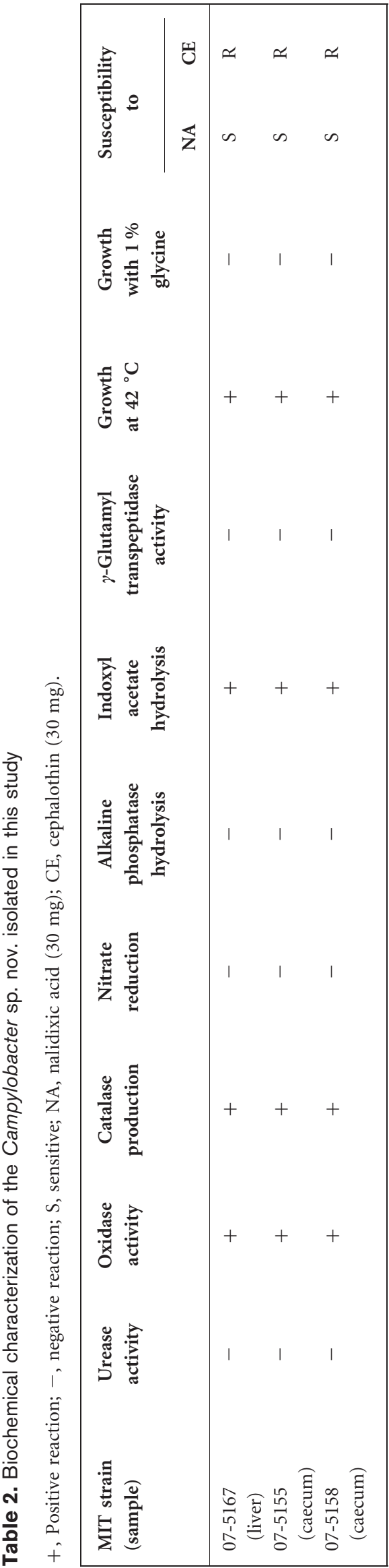

\section{RFLP analysis}

By RFLP analysis of the $1.2 \mathrm{~kb}$ PCR products (Fig. 1), three different RFLP patterns were noted using the restriction enzyme AluI: strains in Fig. 1(a) lanes 1-3 shared a common pattern and corresponded to $16 \mathrm{~S}$ rRNA prairie $\operatorname{dog} 3$ cluster (see below). The profile of the prairie dog isolate in Fig. 1, lane 4, was identical to that of the woodchuck isolate in lane 5 and corresponded to $16 \mathrm{~S}$ rRNA prairie dog 2 cluster. The profiles of the prairie dog isolates in Fig. 1(a), lanes 6 and 7, were identical to that of the woodchuck $H$. marmotae type strain in lane 8 and corresponded to $16 \mathrm{~S}$ rRNA prairie dog 1 cluster. Two patterns were observed using restriction enzyme HhaI: the

(a)

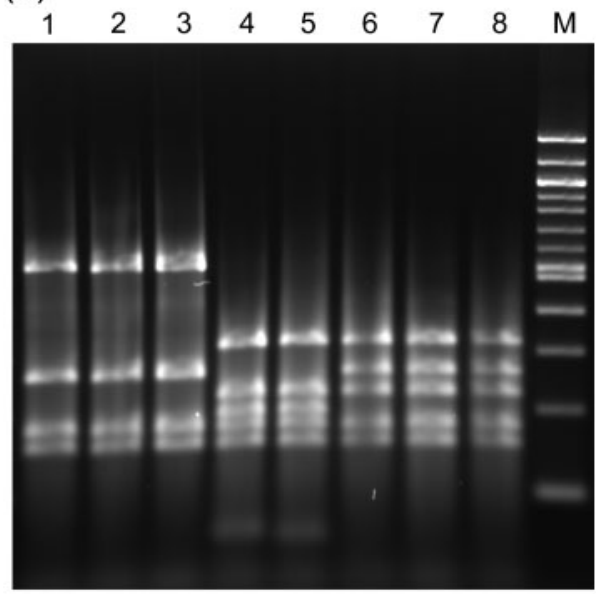

(b)

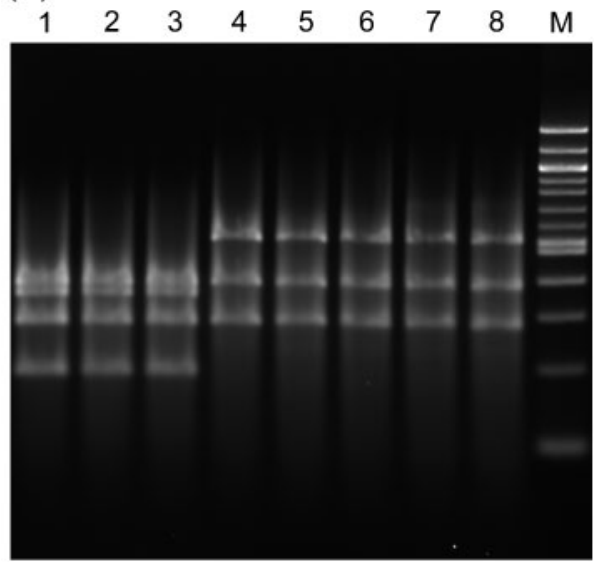

Fig. 1. PCR products of $1.2 \mathrm{~kb}$ produced using Helicobacter genus-specific primers were digested by Alul (a) or thal (b) and analysed by electrophoresis on a $6 \%$ Visigel matrix. Lanes 1-4, prairie dog isolates MIT 07-5168, MIT 07-5167, MIT 04-8588 and MIT 07-5165; lane 5, woodchuck faecal isolate MIT 02-6901; lanes 6 and 7, prairie dog isolates MIT 04-8589 and MIT 04-8584; lane 8, H. marmotae MIT 98-6070 isolated from woodchuck liver; M, 100 bp DNA ladder. 
isolates corresponding to $16 \mathrm{~S}$ rRNA prairie dog cluster 3 had one pattern (Fig. 1b, lanes 1-3), whilst the remaining isolates and H. marmotae showed a second pattern (Fig. 1b, lanes 4-8).

\section{5 rRNA gene sequence analysis}

As shown in Fig. 2, the prairie dog helicobacters fell into three clusters adjacent to $H$. marmotae. Prairie dog 1 cluster contained strains MIT 04-8584 and MIT 04-8589, which were $99.0 \%$ similar to the sequence of $H$. marmotae and contained a $295 \mathrm{bp}$ intervening sequence (IVS) in the helix at nt 198-219 (Escherichia coli numbering), which has not been noted in other $H$. marmotae strains. This IVS was about $80 \%$ similar to the IVS in Helicobacter muricola. Prairie dog 2 cluster contained strain MIT 07-5165 and was $98.6 \%$ similar to $H$. marmotae and also contained a $295 \mathrm{bp}$ IVS essentially identical to that of the prairie dog 1 strains. On the basis of $16 \mathrm{~S}$ rRNA gene sequence and phenotypic properties, we propose that the three strains in prairie dog clusters 1 and 2 be included in the species $H$. marmotae. The three prairie dog 3 cluster strains MIT 04-8588, MIT 07-5167 and MIT $07-5168$ were only $97.1 \%$ similar to the sequence of $H$. marmotae and should be considered a novel species.

The three prairie dog campylobacters formed a single identifiable cluster (Fig. 3). They branched with C. cuniculorum with $96.3 \%$ similarity and had a sequence similarity to
C. helveticus of $97.1 \%$. Based on $16 \mathrm{~S}$ rRNA analysis, these strains represent a novel Campylobacter species.

\section{Histopathology}

In all five animals, the most consistent findings noted in livers included mild portal lymphocytic inflammation, mild bile duct and arteriolar proliferation, and mild centrilobular fatty changes. Interestingly, the livers of three of the prairie dogs, two of which were positive for Helicobacter species by nested PCR, also had mild accumulations of neutrophils and myeloid precursor cells along the capsular border. Although the precursor cells indicated extramedullary haematopoiesis in the liver, the mature neutrophils suggested a degree of peritonitis, although the cause of this was not identified histologically. The most significant lesion was the hepatocellular carcinoma seen in the liver of animal 08-9090, which was one of the prairie dogs whose liver was positive for Helicobacter species by nested PCR (Fig. 4). This tumour comprised a variably well-demarcated proliferation of neoplastic cells with hepatocellular differentiation. Cells formed trabeculae and nests (often composed of more than ten cell layers), separated by a fine connective tissue stroma and were round to polygonal with abundant eosinophilic cytoplasm and a single, round nucleus with a prominent nucleolus. Nuclear and cellular pleomorphisms were mild, and the number of mitoses was between zero and five per ten objective fields $(\times 40)$. Occasional attempts at acinar

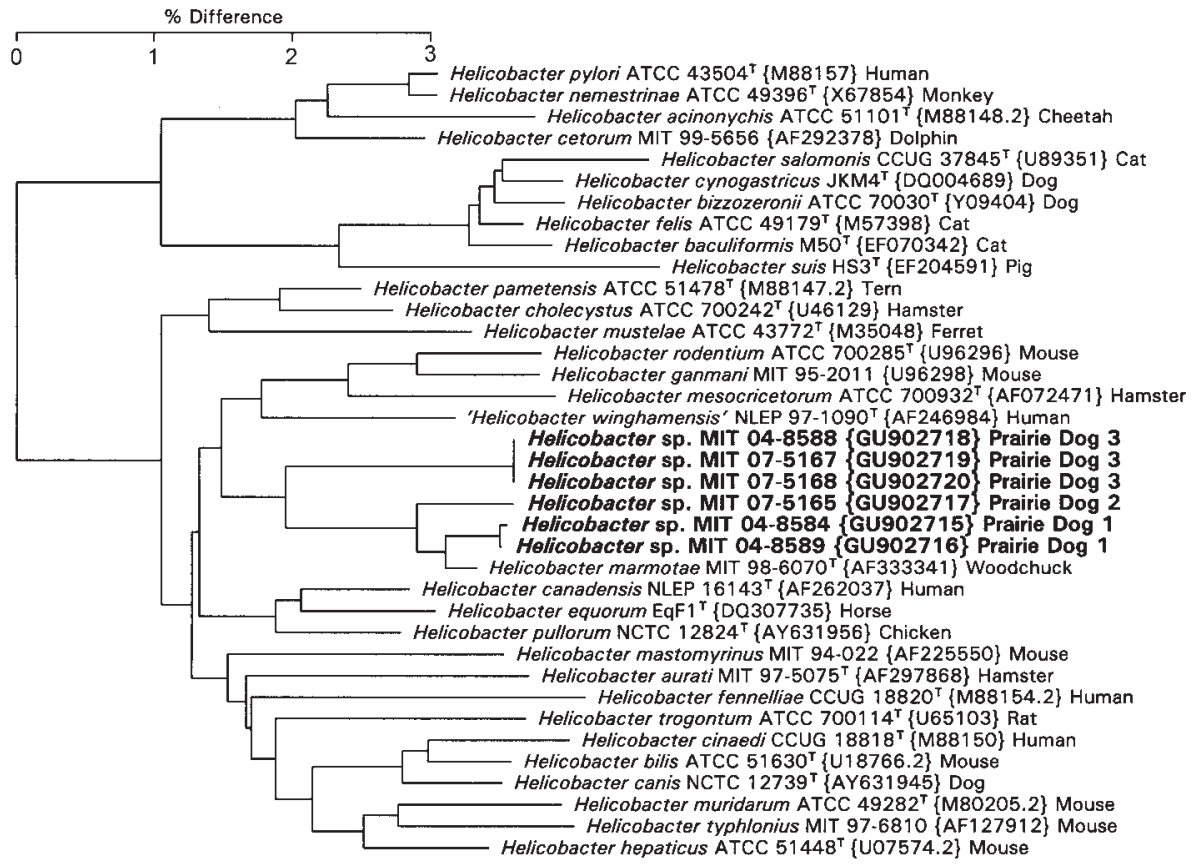

Fig. 2. Neighbour-joining tree for prairie dog Helicobacter isolates based on comparison of 16S rRNA gene sequences. Bar, percentage difference in nucleotide sequence. GenBank accession numbers are shown in brackets and host species is indicated. Numbers in bold are isolates described in this study. 


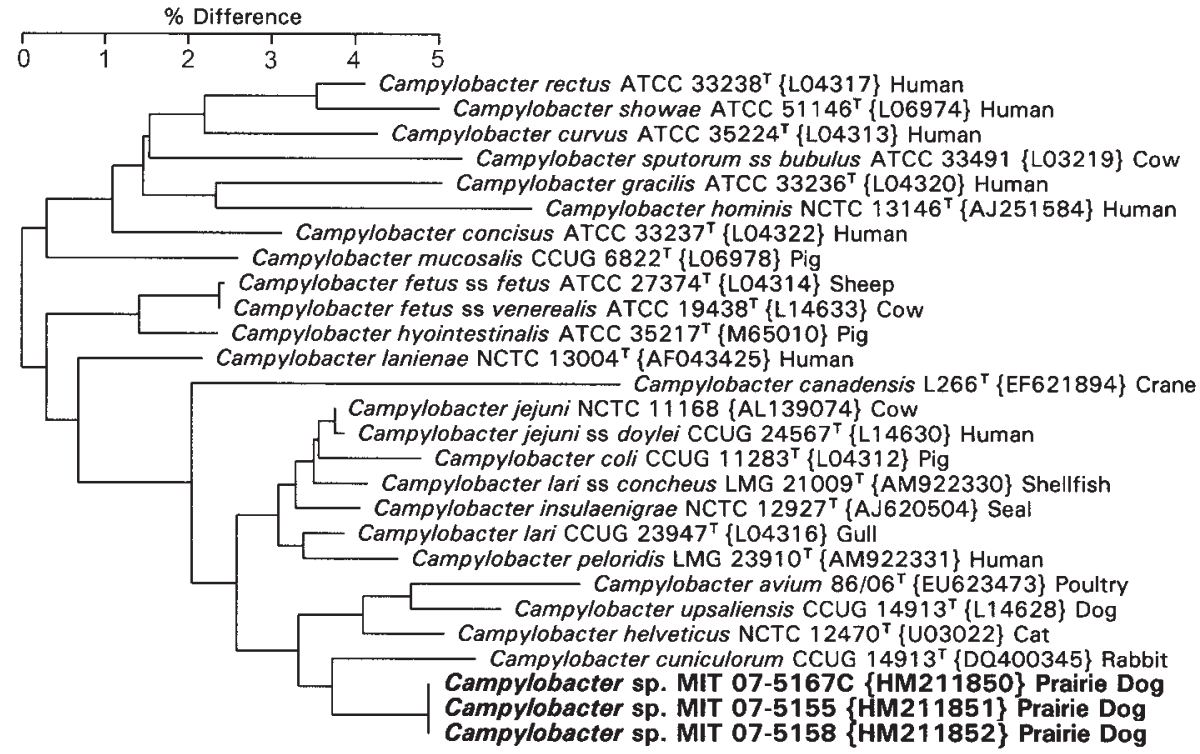

Fig. 3. Neighbour-joining tree for prairie dog Campylobacter isolates based on comparison of $16 \mathrm{~S}$ rRNA gene sequences. Bar, percentage difference in nucleotide sequence. GenBank accession numbers are shown in brackets and host species is indicated. Numbers in bold are isolates described in this study.

formation were seen. Extensive intratumoral haemorrhage, necrosis and intracellular fatty changes were also seen.

\section{DISCUSSION}

Prairie dogs are used mostly in gallbladder studies, particularly in experiments involving cholesterol gallstones (Abedin et al., 2001; Davis et al., 2003; Narins et al., 2005; Strichartz et al., 1989). The advantages of utilizing the prairie dog gallstone model are the similarity of the prairie dog and human bile and gallstone composition and the reliability of sufficient quantities of bile, cholesterol stones and tissue for analysis (Brenneman et al., 1972). The isolation of Helicobacter marmotae-like organisms from the liver of a prairie dog being used to study cholesterol gallstone formation raises the number of Helicobacter species isolated from the livers of mammals and birds to ten. The other Helicobacter species isolated from animal livers include Helicobacter bilis and Helicobacter hepaticus cultured from mice (Fox et al., 1994, 1995, 1996c), H. bilis from hamsters (Fox et al., 2009), Helicobacter cholecystus from hamsters (Franklin et al., 1996), Helicobacter canis from dogs (Fox et al., 1996a), Helicobacter cinaedi from monkeys (Fox et al., 2001) and Helicobacter sp. flexispira taxa 2 and 5 from sheep (Kirkbride et al., 1985). $H$. marmotae has been cultured from the liver of woodchucks and the faeces of cats (Fox et al., 2002) and Helicobacter pullorum from chicken livers and mouse intestines (Boutin et al., 2010; Stanley et al., 1994).

Recent experimental results and epidemiological studies suggest a possible association between enterohepatic
Helicobacter species and cholesterol cholelithiasis, chronic cholecystitis and gallbladder cancer. Our laboratory prospectively investigated the effect of infection by Helicobacter species in cholesterol gallstone pathogenesis in the highly susceptible C57L/J mouse model (Maurer et al., 2005). Helicobacter-free adult male C57L mice were infected with several different enterohepatic helicobacters or left uninfected and fed either a lithogenic diet or standard mouse chow for 8 and 18 weeks. At the conclusion of the study, bile was examined microscopically, and diagnostic culture and PCR were performed. Mice infected with $H$. bilis or co-infected with $H$. hepaticus and Helicobacter rodentium and fed a lithogenic diet developed cholesterol gallstones at $80 \%$ prevalence by 8 weeks compared with approximately $10 \%$ in uninfected controls. Monoinfections with $H$. hepaticus, $H$. cinaedi and $H$. rodentium gave a cholesterol gallstone prevalence of 40,30 and $20 \%$, respectively; the latter two groups did not differ statistically from controls. Neither infected nor uninfected mice fed a standard chow diet developed cholesterol gallstones. These findings suggest that Helicobacter species may play a role in the pathophysiology of cholesterol gallstone formation in mice (Maurer et al., 2005). We have also previously documented Helicobacter species in Chilean females with chronic cholecystitis and cholesterol gallstones (Fox et al., 1998). Others have documented Helicobacter species in a variety of hepatobiliary diseases in humans (reviewed by Pellicano et al., 2008).

In this study, H. marmotae was isolated from caeca of two prairie dogs and identified by PCR and sequencing of a 700 bp PCR product in the liver of two additional prairie dogs. Helicobacter species have been detected in various other wild rodents (Comunian et al., 2006; Fox et al., 2002; 

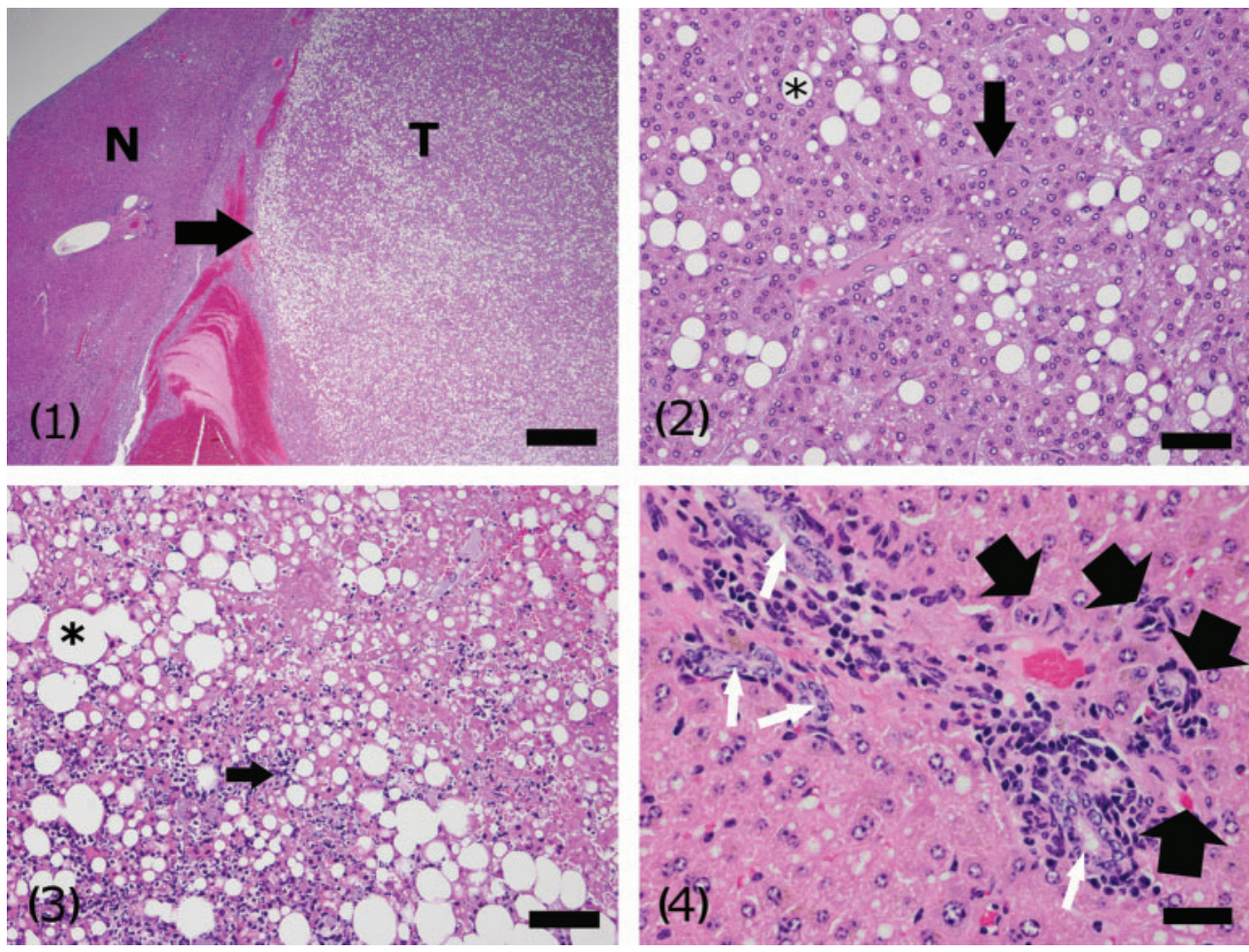

Fig. 4. Hepatocellular carcinoma seen in the liver of prairie dog 08-9090, whose liver was positive for Helicobacter species by nested PCR. (1) Normal liver parenchyma $(\mathrm{N})$ is expanded by a tumour (T). An arrow marks the zone of demarcation between normal liver parenchyma and the hepatocellular carcinoma. Bar, $500 \mu \mathrm{m}$. (2) A fine connective tissue stroma (arrow) delineates nests of well-differentiated, neoplastic hepatocytes. Lipid vacuoles $\left(^{*}\right)$ scattered throughout characterize the fatty changes within the tumour. Bar, $50 \mu \mathrm{m}$. (3) A zone of liquefactive necrosis within the tumour, with characteristic loss of cell detail and mixed, large amounts of neutrophilic cell debris (arrow). Fatty changes are again evident by the presence of lipid vacuoles $\left({ }^{*}\right)$. Bar, $50 \mu \mathrm{m}$. (4) A portal area within the non-tumorous region of the liver is expanded by proliferations of bile ducts (white arrows) and arterioles (black arrows). Increased numbers of lymphocytes also surround the bile ducts. Bar, $20 \mu \mathrm{m}$.

Parker et al., 2009; Won et al., 2002). H. hepaticus, Helicobacter apodemus, Helicobacter canadensis and $H$. winghamensis were identified by partial 16S rRNA gene sequence analysis, suggesting that enteric Helicobacter infections may be widespread in wild rodents in China (Goto et al., 2004). H. muricola was isolated and characterized in Korean wild mice (Won et al., 2002). Comunian et al. (2006) also detected Helicobacter DNA by PCR in faeces of wild rodents in Brazil. Species tentatively identified included H. marmotae, $H$. cinaedi and $H$. rodentium (Comunian et al., 2006).

Five out of 12 Helicobacter-positive prairie dogs were coinfected with Campylobacter species Three of the Campylobacter strains whose $16 \mathrm{~S}$ rRNA gene was sequenced were considered a novel species, related to C. cuniculorum and $C$. helveticus. This finding of co-infection is not surprising given that enteric helicobacters are often found in hosts coinfected with Campylobacter species. For example, 64/227 commercially reared cats had microaerophilic bacteria isolated from their faeces that were initially identified as Campylobacter-like organisms based on biochemical and phenotypic characteristics (Shen et al., 2001). DNA extractions were subjected to PCR using primers specific for Helicobacter species and Campylobacter species. Of the isolates, $92 \%$ (47/51) were positive for Campylobacter species, $41 \%$ (21/51 isolates) were positive for Helicobacter species and $33 \%$ (17/51 isolates) were positive for both genera. Co-infection with Campylobacter species, enteric Helicobacter species and Anaerobiospirillum species in 52 healthy and 138 diarrhoeic dogs and in 63 diarrhoeic and 21 healthy cats has been reported (Rossi et al., 2008); about $10 \%$ of both dogs and cats were found to be co-infected with Campylobacter species and Helicobacter species. However, no statistically significant correlation between isolation of single or mixed infections and the presence of diarrhoea was observed (Rossi et al., 2008).

Investigators in South Africa have published results for a protocol that allows primary isolation of multiple Campylobacter species and Helicobacter species from the diarrhoeic specimens of individual children. Filtrates are plated onto antibiotic-free blood agar plates and incubated in an $\mathrm{H}_{2}$ enriched atmosphere (Lastovica \& le Roux, 2000). The authors reported a $16 \%$ prevalence of multiple Campylobacter 
species and Helicobacter species based on primary isolation and biochemical characterization. They frequently recovered between two and five species of Campylobacter and Helicobacter from single stool samples, with Campylobacter jejuni, Campylobacter coli, Campylobacter upsaliensis, Helicobacter fennelliae and $H$. cinaedi being commonly isolated (Lastovica \& le Roux, 2000).

Recently, we reported that $H$. marmotae can successfully colonize mice and cause enterohepatic disease (Patterson et al., 2010). Inflammatory lesions present in the livers of five prairie dogs and a hepatocellular carcinoma in a prairie dog whose liver was positive for Helicobacter species by PCR may be related to Helicobacter infection, as noted in $H$. marmotae-infected mice or mice infected with $H$. hepaticus (Fox et al., 1996b, 2011; García et al., 2008; Patterson et al., 2010). Isolation and identification of a novel Campylobacter from the intestine and liver of prairie dogs is also interesting. Experimentally, C. jejuni can induce chronic hepatitis in mice (Kita et al., 1986, 1990, 1992). It is also interesting to note the gender differences in the presence of Helicobacter species and Campylobacter species in the prairie dog. Helicobacter species were detected in nine out of 20 males and three out of 14 females, whilst Campylobacter species were detected in three out of 20 males and seven out of 14 females. It is not known whether a female gender bias of Campylobacter species is associated with the female gender bias of gallstone and gallbladder cancer incidence in humans. Our results suggest that further studies examining the role of $H$. marmotae, other Helicobacter species and Campylobacter species in the pathogenesis of cholesterol gallstones and chronic inflammation in the liver and intestine in this prairie dog model should be conducted.

\section{ACKNOWLEDGEMENTS}

This study was supported by National Institutes of Health grants R01CA067529, R01DK052413, T32RR007036, P30ES002109, P01CA 026731 (all to J. G.F.) and R01DK070865 (M. Z. A.).

\section{REFERENCES}

Abedin, M. Z., Giurgiu, D. I., Abedin, Z. R., Peck, E. A., Su, X. \& Smith, P. R. (2001). Characterization of $\mathrm{Na}^{+} / \mathrm{H}^{+}$exchanger isoform (NHE1, NH32 and NHE3) expression in prairie dog gallbladder. J Membr Biol 182, 123-134.

Bohr, U. R., Primus, A., Zagoura, A., Glasbrenner, B., Wex, T. \& Malfertheiner, P. (2002). A group-specific PCR assay for the detection of Helicobacteraceae in human gut. Helicobacter 7, 378-383.

Boutin, S. R., Shen, Z., Roesch, P. L., Stiefel, S. M., Sanderson, A. E., Multari, H. M., Pridhoko, E. A., Smith, J. C., Taylor, N. S. \& other authors (2010). Helicobacter pullorum outbreak in C57BL/6NTac and C3H/HeNTac barrier-maintained mice. J Clin Microbiol 48, 19081910.

Brenneman, D. E., Connor, W. E., Forker, E. L. \& DenBesten, L. (1972). The formation of abnormal bile and cholesterol gallstones from dietary cholesterol in the prairie dog. J Clin Invest 51, 1495-1503.

Comunian, L. B., Moura, S. B., Paglia, A. P., Nicoli, J. R., Guerra, J. B., Rocha, G. A. \& Queiroz, D. M. (2006). Detection of Helicobacter species in the gastrointestinal tract of wild rodents from Brazil. Curr Microbiol 53, 370-373.

Davis, K. G., Wertin, T. M. \& Schriver, J. P. (2003). The use of simvastatin for the prevention of gallstones in the lithogenic prairie dog model. Obes Surg 13, 865-868.

Dewhirst, F. E., Chien, C.-C., Paster, B. J., Ericson, R. L., Orcutt, R. P., Schauer, D. B. \& Fox, J. G. (1999). Phylogeny of the defined murine microbiota: altered Schaedler flora. Appl Environ Microbiol 65, 32873292.

Fox, J. G. (2002). The non- $H$. pylori helicobacters: their expanding role in gastrointestinal and systemic diseases. Gut 50, 273-283.

Fox, J. G. \& Wang, T. C. (2007). Inflammation, atrophy, and gastric cancer. J Clin Invest 117, 60-69.

Fox, J. G., Dewhirst, F. E., Tully, J. G., Paster, B. J., Yan, L., Taylor, N. S., Collins, M. J., Jr, Gorelick, P. L. \& Ward, J. M. (1994). Helicobacter hepaticus sp. nov., a microaerophilic bacterium isolated from livers and intestinal mucosal scrapings from mice. J Clin Microbiol 32, 1238-1245.

Fox, J. G., Yan, L. L., Dewhirst, F. E., Paster, B. J., Shames, B., Murphy, J. C., Hayward, A., Belcher, J. C. \& Mendes, E. N. (1995). Helicobacter bilis sp. nov., a novel Helicobacter species isolated from bile, livers, and intestines of aged, inbred mice. J Clin Microbiol 33, 445-454.

Fox, J. G., Drolet, R., Higgins, R., Messier, S., Yan, L., Coleman, B. E., Paster, B. J. \& Dewhirst, F. E. (1996a). Helicobacter canis isolated from a dog liver with multifocal necrotizing hepatitis. J Clin Microbiol 34, 2479-2482.

Fox, J. G., Li, X., Yan, L., Cahill, R. J., Hurley, R., Lewis, R. \& Murphy, J. C. (1996b). Chronic proliferative hepatitis in A/JCr mice associated with persistent Helicobacter hepaticus infection: a model of helicobacter-induced carcinogenesis. Infect Immun 64, 1548-1558.

Fox, J. G., Yan, L., Shames, B., Campbell, J., Murphy, J. C. \& Li, X. (1996c). Persistent hepatitis and enterocolitis in germfree mice infected with Helicobacter hepaticus. Infect Immun 64, 3673-3681.

Fox, J. G., Dewhirst, F. E., Shen, Z., Feng, Y., Taylor, N. S., Paster, B. J., Ericson, R. L., Lau, C. N., Correa, P. \& other authors (1998). Hepatic Helicobacter species identified in bile and gallbladder tissue from Chileans with chronic cholecystitis. Gastroenterology 114, 755-763.

Fox, J. G., Handt, L., Sheppard, B. J., Xu, S., Dewhirst, F. E., Motzel, S. \& Klein, H. (2001). Isolation of Helicobacter cinaedi from the colon, liver, and mesenteric lymph node of a rhesus monkey with chronic colitis and hepatitis. J Clin Microbiol 39, 1580-1585.

Fox, J. G., Shen, Z., Xu, S., Feng, Y., Dangler, C. A., Dewhirst, F. E., Paster, B. J. \& Cullen, J. M. (2002). Helicobacter marmotae sp. nov. isolated from livers of woodchucks and intestines of cats. J Clin Microbiol 40, 2513-2519.

Fox, J. G., Taylor, N. S., Howe, S., Tidd, M., Xu, S., Paster, B. J. \& Dewhirst, F. E. (2006). Helicobacter anseris sp. nov. and Helicobacter brantae sp. nov., isolated from feces of resident Canada geese in the greater Boston area. Appl Environ Microbiol 72, 4633-4637.

Fox, J. G., Shen, Z., Muthupalani, S., Rogers, A. R., Kirchain, S. M. \& Dewhirst, F. E. (2009). Chronic hepatitis, hepatic dysplasia, fibrosis, and biliary hyperplasia in hamsters naturally infected with a novel Helicobacter classified in the H. bilis cluster. J Clin Microbiol 47, 36733681.

Fox, J. G., Feng, Y., Theve, E. J., Raczynski, A. R., Fiala, J. L., Doernte, A. L., Williams, M., McFaline, J. L., Essigmann, J. M. \& other authors (2010). Gut microbes define liver cancer risk in mice exposed to chemical and viral transgenic hepatocarcinogens. Gut 59, 88-97.

Fox, J. G., Ge, Z., Whary, M. T., Erdman, S. E. \& Horwitz, B. H. (2011). Helicobacter hepaticus infection in mice: models for understanding lower bowel inflammation and cancer. Mucosal Immunol 4, 22-30. 
Franklin, C. L., Beckwith, C. S., Livingston, R. S., Riley, L. K., Gibson, S. V., Besch-Williford, C. L. \& Hook, R. R., Jr (1996). Isolation of a novel Helicobacter species, Helicobacter cholecystus sp. nov., from the gallbladders of Syrian hamsters with cholangiofibrosis and centrilobular pancreatitis. J Clin Microbiol 34, 2952-2958.

García, A., Ihrig, M. M., Fry, R. C., Feng, Y., Xu, S., Boutin, S. R., Rogers, A. B., Muthupalani, S., Samson, L. D. \& Fox, J. G. (2008). Genetic susceptibility to chronic hepatitis is inherited codominantly in Helicobacter hepaticus-infected AB6F1 and B6AF1 hybrid male mice, and progression to hepatocellular carcinoma is linked to hepatic expression of lipogenic genes and immune function-associated networks. Infect Immun 76, 1866-1876.

Goto, K., Jiang, W., Zheng, Q., Oku, Y., Kamiya, H., Itoh, T. \& Ito, M. (2004). Epidemiology of Helicobacter infection in wild rodents in the Xinjiang-Uygur autonomous region of China. Curr Microbiol 49, 221-223.

Kirkbride, C. A., Gates, C. E., Collins, J. E. \& Ritchie, A. E. (1985). Ovine abortion associated with an anaerobic bacterium. J Am Vet Med Assoc 186, 789-791.

Kita, E., Katsui, N., Nishi, K., Emoto, M., Yanagase, Y. \& Kashiba, S. (1986). Hepatic lesions in experimental Campylobacter jejuni infection of mice. J Gen Microbiol 132, 3095-3103.

Kita, E., Oku, D., Hamuro, A., Nishikawa, F., Emoto, M., Yagyu, Y., Katsui, N. \& Kashiba, S. (1990). Hepatotoxic activity of Campylobacter jejuni. J Med Microbiol 33, 171-182.

Kita, E., Nishikawa, F., Kamikaidou, N., Nakano, A., Katsui, N. \& Kashiba, S. (1992). Mononuclear cell response in the liver of mice infected with hepatotoxigenic Campylobacter jejuni. J Med Microbiol 37, 326-331.

Kobayashi, T., Harada, K., Miwa, K. \& Nakanuma, Y. (2005). Helicobacter genus DNA fragments are commonly detectable in bile from patients with extrahepatic biliary diseases and associated with their pathogenesis. Dig Dis Sci 50, 862-867.

Lastovica, A. J. \& le Roux, E. (2000). Efficient isolation of campylobacteria from stools. J Clin Microbiol 38, 2798-2799.

Li, Y. F., Russell, D. H., Myers, S. I., Weisbrodt, N. W. \& Moody, F. G. (1994). Gallbladder contractility in aspirin- and cholesterol-fed prairie dogs. Gastroenterology 106, 1662-1667.

Marini, R. P., Muthupalani, S., Shen, Z., Buckley, E. M., Alvarado, C., Taylor, N. S., Dewhirst, F. E., Whary, M. T., Patterson, M. M. \& Fox, J. G. (2010). Persistent infection of rhesus monkeys with 'Helicobacter macacae' and its isolation from an animal with intestinal adenocarcinoma. J Med Microbiol 59, 961-969.

Maurer, K. J., Ihrig, M. M., Rogers, A. B., Ng, V., Bouchard, G., Leonard, M. R., Carey, M. C. \& Fox, J. G. (2005). Identification of cholelithogenic enterohepatic helicobacter species and their role in murine cholesterol gallstone formation. Gastroenterology 128, 1023-1033.
Moser, A. J., Gangopadhyay, A., Bradbury, N. A., Peters, K. W., Frizzell, R. A. \& Bridges, R. J. (2007). Electrogenic bicarbonate secretion by prairie dog gallbladder. Am J Physiol Gastrointest Liver Physiol 292, G1683-G1694.

Narins, S. C., Ramakrishnan, R., Park, E. H., Bolno, P. B., Haggerty, D. A., Smith, P. R., Meyers, W. C. \& Abedin, M. Z. (2005). Protein kinase C- $\alpha$ regulation of gallbladder $\mathrm{Na}^{+}$transport becomes progressively more dysfunctional during gallstone formation. J Lab Clin Med 146, 227-237.

Parker, S. E., Malone, S., Bunte, R. M. \& Smith, A. L. (2009). Infectious diseases in wild mice (Mus musculus) collected on and around the University of Pennsylvania (Philadelphia) Campus. Comp Med 59, 424-430.

Patterson, M. M., Rogers, A. B. \& Fox, J. G. (2010). Experimental Helicobacter marmotae infection in A/J mice causes enterohepatic disease. J Med Microbiol 59, 1235-1241.

Pellicano, R., Ménard, A., Rizzetto, M. \& Mégraud, F. (2008). Helicobacter species and liver diseases: association or causation? Lancet Infect Dis 8, 254-260.

Rossi, M., Hänninen, M. L., Revez, J., Hannula, M. \& Zanoni, R. G. (2008). Occurrence and species level diagnostics of Campylobacter spp., enteric Helicobacter spp. and Anaerobiospirillum spp. in healthy and diarrheic dogs and cats. Vet Microbiol 129, 304-314.

Saitou, N. \& Nei, M. (1987). The neighbor-joining method: a new method for reconstructing phylogenetic trees. Mol Biol Evol 4, 406-425.

Shen, Z., Feng, Y. \& Fox, J. G. (2000). Identification of enterohepatic Helicobacter species by restriction fragment-length polymorphism analysis of the 16S rRNA gene. Helicobacter 5, 121-128.

Shen, Z., Feng, Y., Dewhirst, F. E. \& Fox, J. G. (2001). Coinfection of enteric Helicobacter spp. and Campylobacter spp. in cats. J Clin Microbiol 39, 2166-2172.

Stanley, J., Linton, D., Burnens, A. P., Dewhirst, F. E., On, S. L., Porter, A., Owen, R. J. \& Costas, M. (1994). Helicobacter pullorum sp. nov. genotype and phenotype of a new species isolated from poultry and from human patients with gastroenteritis. Microbiology 140, 3441-3449.

Strichartz, S. D., Abedin, M. Z., Abdou, M. S. \& Roslyn, J. J. (1989). The effects of amiloride on biliary calcium and cholesterol gallstone formation. Ann Surg 209, 152-156.

Whary, M. T. \& Fox, J. G. (2004). Natural and experimental Helicobacter infections. Comp Med 54, 128-158.

Won, Y. S., Yoon, J. H., Lee, C. H., Kim, B. H., Hyun, B. H. \& Choi, Y. K. (2002). Helicobacter muricola sp. nov., a novel Helicobacter species isolated from the ceca and feces of Korean wild mouse (Mus musculus molossinus). FEMS Microbiol Lett 209, 45-51.

Zenner, L. (1999). Pathology, diagnosis and epidemiology of the rodent Helicobacter infection. Comp Immunol Microbiol Infect Dis 22, $41-61$. 